Bulgarian Academy of Sciences. Space Research and Technology Institute.

Aerospace Research in Bulgaria. 29, 2017, Sofia

\title{
DEVELOPMENT OF ADVANCED SPACE SCIENCES AFTER FIRST ARTIFICIAL SATELLITE. 60-TH ANNIVERSARY OF THE SPACE AGE
}

\author{
Peter I. Y. Velinov \\ Space Research and Technology Institute - Bulgarian Academy of Sciences \\ e-mail:pvelinov@bas.bg
}

\begin{abstract}
The development of the various space sciences has been demonstrated since the launch of the first artificial Earth's satellite "Sputnik 1" on 04 October 1957. A number of data and characteristics for this satellite are presented in the present work.

There are also the first discoveries (1957-1958) in space age - the van Allen-Vernov radiation belts of the Earth. The history of radio observation of "Sputnik 1" in the 22-day period 04-26 October 1957, of satellite transmitter operation was presented.

The first radio measurements in Bulgaria were made by Dr. G. Nestorov (later professor and correspondent member of BAS) from the Special department established at the beginning of 1957 in the Research Institute for Communications - Radio-measuring Control and Ionospheric Center RIKIC. Dr. G. Nestorov makes measurements of the effect of Doppler and determines the height of the satellite. He finds that during the second and third week, "Sputnik 1" begins to noticeably reduce its height due to its drag and friction with the substance in the upper atmosphere.

Subsequently, after 1958, optical, laser and radar observations of artificial satellites on Earth began to take place in Bulgaria. During the period 1958-1959 three observation stations were set up - in Sofia, Stara Zagora and Varna. These observations continue until 2002, when they are gradually ceased to be done due to a lack of funding and the moving of the world observation centers to a higher technological level.
\end{abstract}

\section{Introduction}

The year 2017 marks the $60^{\text {th }}$ anniversary of the arrival of the space age. On 4 October 1957, our planet’s first artificial satellite, "Sputnik 1" (Russian for "satellite") - Fig. 1, was launched into low-Earth orbit by the Soviet Union. Although little more than a radio beacon, it showed the world that intercontinental ballistic missiles (ICBMs), at the core of Cold War military arsenals, could also place satellites into space. A mere month later, on 3 November, Soviet scientists launched a much larger and more sophisticated spacecraft - "Sputnik 2", the 
second satellite sent into orbit and the first with a live animal - the dog Laika; a model with a doll stand-in is pictured in Fig. 2. The event was timed to coincide with the eve of the $40^{\text {th }}$ anniversary of the Bolshevik Revolution.

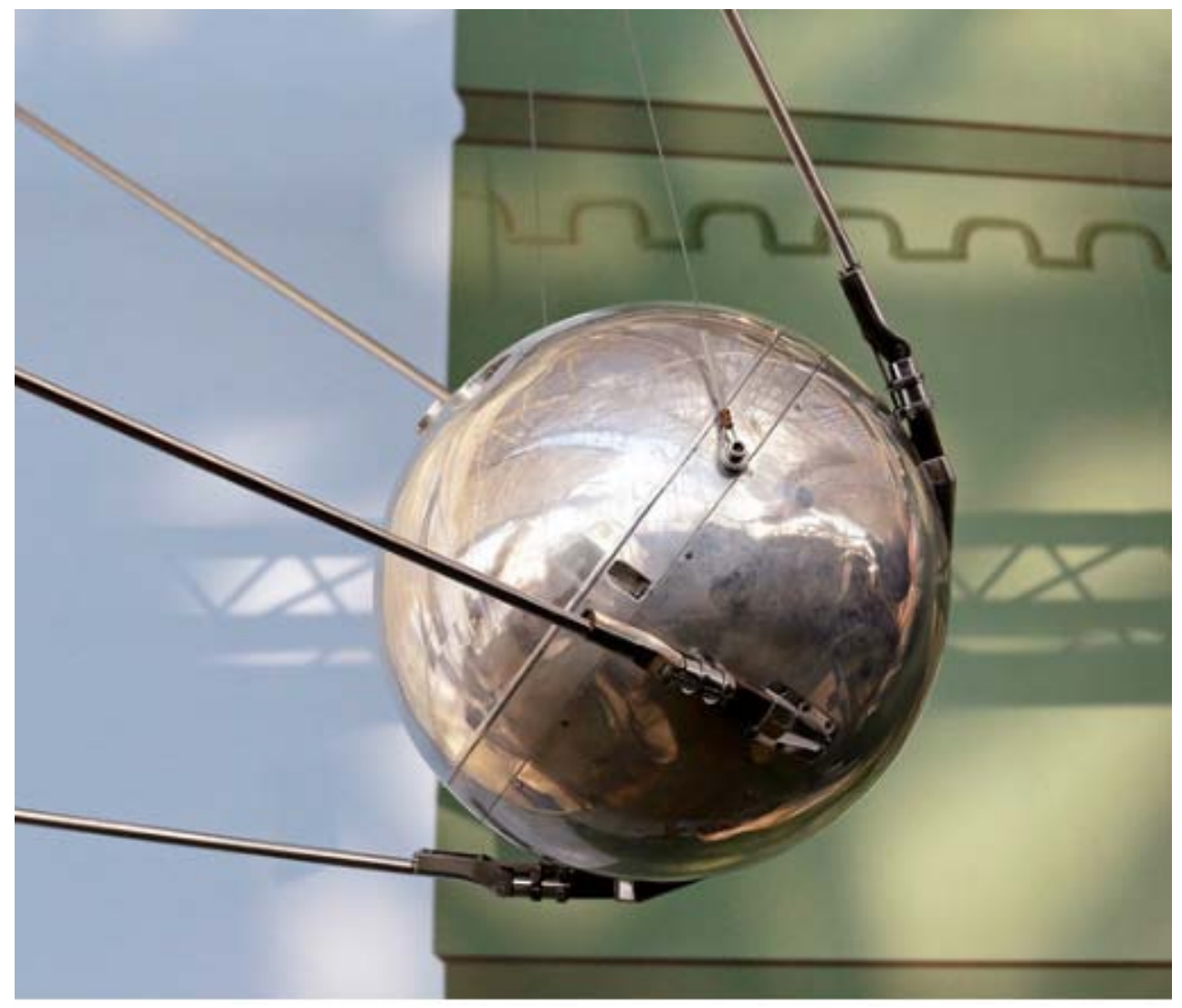

Fig. 1. A replica of Sputnik 1, the first artificial satellite in the world to be put into outer space: the replica is stored in Russian National Museum of the First Flight 


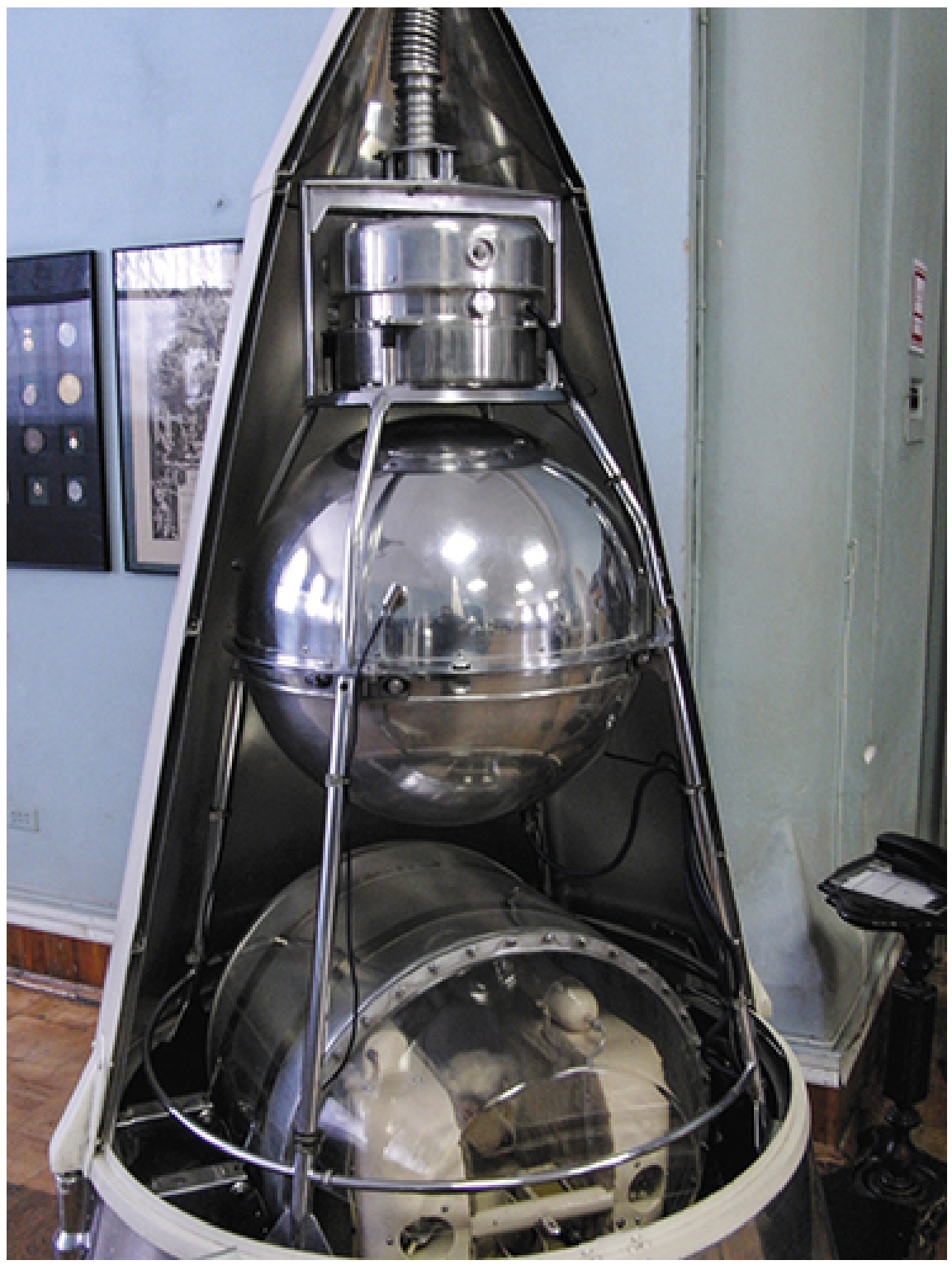

Fig. 2. Sputnik 2 was a 4-meter-tall, cone-shaped capsule designed to remain attached to the rocket that launched it into orbit on 3 November 1957. It held radio transmitters, a telemetry system, a Geiger counter, and a temperature-control system for the cabin, which carried the dog Laika. The model shown here is now at the Polytechnical Museum in Moscow. 
The arrival of the space age has led to the creation and development of a number of new space sciences: aeronautics and astronautics or cosmonautics aerospace engineering, space navigation, space communications, space astronomy, space physics, space weather and space climate, space climatology, extrasolar planetary systems, exoplanetology, space chemistry or cosmochemistry, cosmic ray physics, heliospheric physics, planetary magnetospheres and ionospheres, Earth's space environment, space geophysics, space meteorology, space medicine and biology, micro-g environment research, space dosimetry, aerospace technology, space materials science, space dynamics, remote sensing from space, space exploration, space colonization, space law, and many others. With the help of these advanced space sciences humanity began confidently the exploration of space. But these studies led also to numerous new technologies and applications to improve people's lives.

\section{Sputnik-1 proclaimed the arrival of space age on 4 October 1957}

"Sputnik 1" ("Satellite-1", or "PS-1", Простейший Спутник-1, "Elementary Satellite 1") was the first artificial Earth satellite. The Soviet Union launched it into an elliptical low Earth orbit on 4 October 1957 at 19:28:34 UTC. The satellite had an initial orbit with perigee $228 \mathrm{~km}$ and apogee $939 \mathrm{~km}$ (eccentricity 0.05201 ), an inclination of 65.1 degrees and a period of 96.2 minutes $[1,2]$.

It was a $58.5 \mathrm{~cm}$ diameter polished metal sphere, with four external radio antennas to broadcast radio pulses. Its radio signal was easily detectable even by radio amateurs, and the $65^{\circ}$ inclination and duration of its orbit made its flight path cover virtually the entire inhabited Earth.

Tracking and studying "Sputnik 1" from Earth provided scientists with valuable information, even though the satellite wasn't equipped with sensors. The density of the upper atmosphere could be deduced from its drag on the orbit, and the propagation of its radio signals gave data about the ionosphere.

"Sputnik 1" was launched during the International Geophysical Year from Site No.1/5, at the $5^{\text {th }}$ Tyuratam range, in Kazakh SSR (now known as the Baikonur Cosmodrome). The satellite travelled at about $29000 \mathrm{~km}$ per hour (8 $100 \mathrm{~m} / \mathrm{s}$ ), taking 96.2 minutes to complete each orbit. It transmitted on 20.005 and $40.002 \mathrm{MHz}$, which were monitored by radio operators throughout the world. The signals continued for 21 days until the transmitter batteries ran out on 26 October 1957. Sputnik burned up on 4 January 1958 while reentering Earth's atmosphere, after three months, 1440 completed orbits of the Earth, and a distance travelled of about 70 million $\mathrm{km}$.

At 19.9 seconds after engine cut-off, PS-1 separated from the second stage and the satellite's transmitter was activated. These signals were detected at the IP-1 
station by Junior Engineer-Lieutenant V. G. Borisov, where reception of Sputnik 1's "beep-beep-beep" tones confirmed the satellite's successful deployment. Reception lasted for two minutes, until PS-1 fell below the horizon. The Tral telemetry system on the R-7 core stage continued to transmit and was detected on its second orbit.

The designers, engineers and technicians who developed the rocket and satellite watched the launch from the range. After the launch they drove to the mobile radio station to listen for signals from the satellite. They waited about 90 minutes to ensure that the satellite had made one orbit and was transmitting, before the chief constructor of Sputnik 1 academician Sergej Korolev called Soviet premier Nikita Khrushchev.

On the first orbit the Telegraph Agency of the Soviet Union (TASS) transmitted: "As result of great, intense work of scientific institutes and design bureaus the first artificial Earth satellite has been built". The R-7 core stage, with a mass of $7.5 \mathrm{t}$ and a length of $26 \mathrm{~m}$, also reached Earth orbit and was visible from the ground at night as a first magnitude object following the satellite. Deployable reflective panels were placed on the booster in order to increase its visibility for tracking. The satellite, a small, highly polished sphere, was barely visible at sixth magnitude, and thus more difficult to follow optically. A third object, the payload fairing, also achieved orbit. The core stage of the R-7 remained in orbit for two months until 2 December 1957, while "Sputnik 1" orbited for three months, until 4 January 1958.

The surprise success of "Sputnik 1" precipitated the American Sputnik crisis and triggered the Space Race, a part of the Cold War. The launch ushered in new political, millitary, technological, and scientific developments. The USSR's launch of "Sputnik 1" spurred the USA to create the Advanced Research Projects Agency (ARPA, later DARPA) in February 1958 to regain a technological lead.

The success of "Sputnik 1" seemed to have changed minds around the world regarding a shift in power to the Soviets. In whole world the media and people initially reacted with a mixture of fear for the future, but also amazement about humankind's progress. Many newspapers and magazines heralded the arrival of the Space Age. After a month on November 3, 1957 the Soviet Union launched a second spacecraft containing the dog Laika. It became clear that the first man's flight into space was coming. 

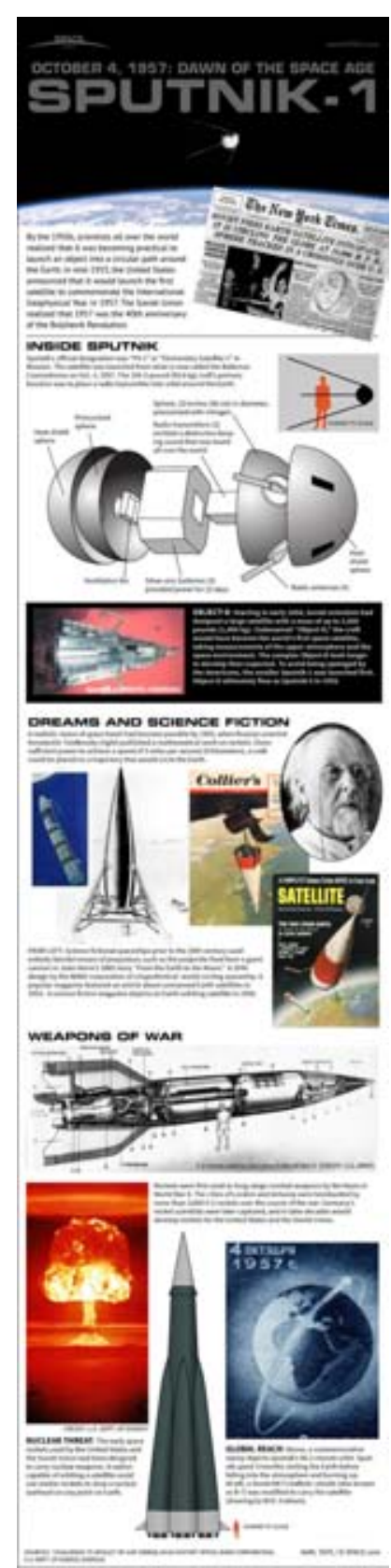

Fig. 3. In the upper part - press releases in the US. At the bottom - schematic of the structure inside the satellite "Sputnik 1" 


\section{Construction}

The chief constructor of "Sputnik 1" at OKB-1 was Sergej Pavlovich Korolev. The satellite was a 585-millimetre diameter sphere, assembled from two hemispheres that were hermetically sealed with o-rings and connected by 36 bolts (Fig. 3, 4). It had a mass of $83.6 \mathrm{~kg}$. The hemispheres were $2 \mathrm{~mm}$ thick, and were covered with a highly polished one-milimeter thick heat shield made of aluminiummagnesium-titanium AMG6T alloy - "AMG" is an abbreviation for "aluminiummagnesium" and "T" stands for "titanium"; the alloy is $6 \%$ magnesium and $0.2 \%$ titanium. The satellite carried two pairs of antennas designed by the Antenna Laboratory of OKB-1 led by Mikhail V. Krayushkin. Each antenna was made up of two whip-like parts: 2.4 and $2.9 \mathrm{~m}$ in length, and had an almost spherical radiation pattern, so that the satellite beeps were transmitted with equal power in all directions, making reception of the transmitted signal independent of the satellite's rotation $[1,2]$.

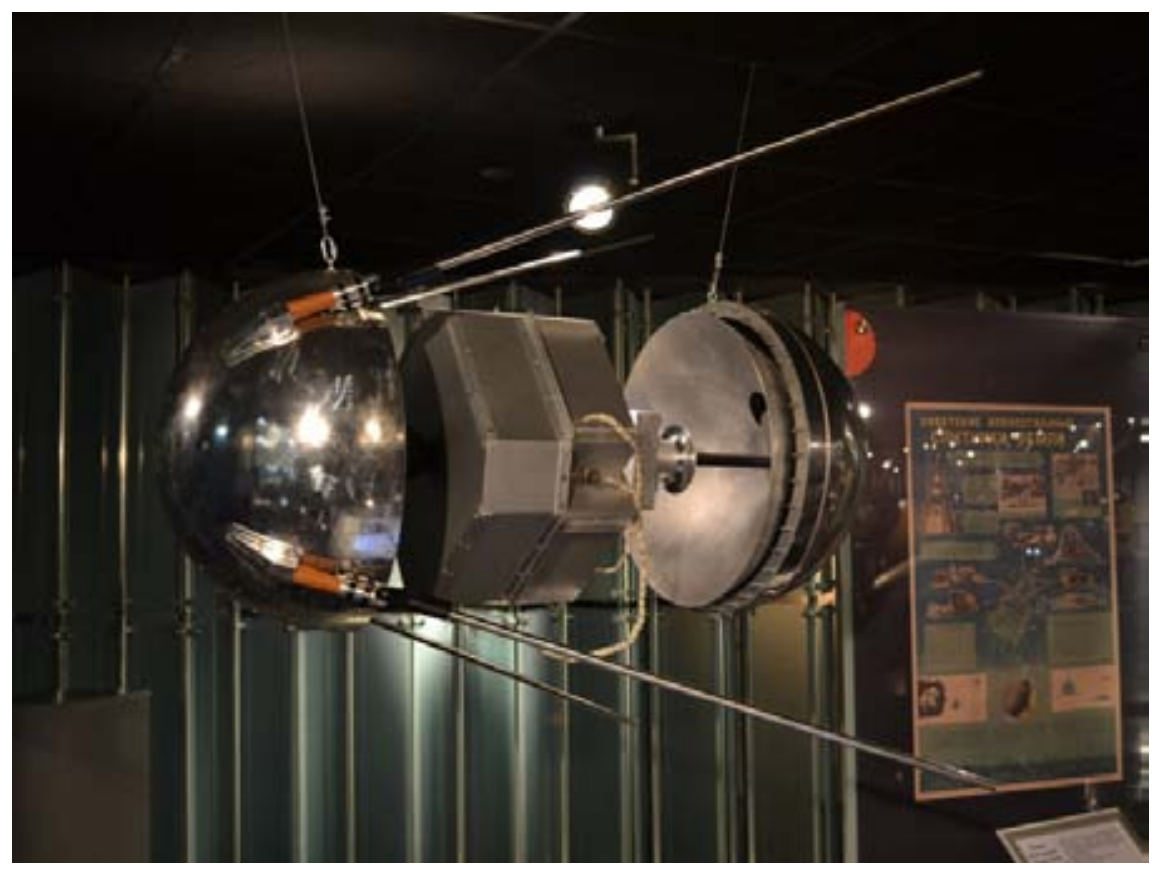

Fig. 4. The structure inside the satellite "Sputnik 1". The model shown here is now at the Polytechnical Museum in Moscow.

The power supply, with a mass of $51 \mathrm{~kg}$, was in the shape of an octagonal nut with the radio transmitter in its hole. It consisted of three Ag-Zn batteries, developed at the All-Union Research Institute of Current Sources (VNIIT) under 
the leadership of Nikolai S. Lidorenko. Two of these batteries powered the radio transmitter and one powered the temperature regulation system. The batteries had an expected lifetime of two weeks, and operated for 22 days. The power supply was turned on automatically at the moment of the satellite's separation from the second stage of the rocket.

The satellite had a one-watt, $3.5 \mathrm{~kg}$ radio transmitting unit inside, developed by Vyacheslav I. Lappo from NII-885, the Moscow Electronics Research Institute, that worked on two frequencies, 20.005 and $40.002 \mathrm{MHz}$. Signals on the first frequency were transmitted in $0.3 \mathrm{sec}$ pulses (under normal temperature and pressure conditions on-board), with pauses of the same duration filled by pulses on the second frequency. Analysis of the radio signals was used to gather information about the electron density of the ionosphere. Temperature and pressure were encoded in the duration of radio beeps. A temperature regulation system contained a fan, a dual thermal switch, and a control thermal switch. If the temperature inside the satellite exceeded $36{ }^{\circ} \mathrm{C}$ the fan was turned on and when it fell below $20^{\circ} \mathrm{C}$ the fan was turned off by the dual thermal switch. If the temperature exceeded $50^{\circ} \mathrm{C}$ or fell below $0{ }^{\circ} \mathrm{C}$, another control thermal switch was activated, changing the duration of the radio signal pulses. "Sputnik 1" was filled with dry nitrogen, pressurized to $1.3 \mathrm{~atm}$. The satellite had a barometric switch, activated if the pressure inside the satellite fell below $130 \mathrm{kPa}$, which would have indicated failure of the pressure vessel or puncture by a meteor, and would have changed the duration of radio signal impulse.

While attached to the rocket, "Sputnik 1" was protected by a cone-shaped payload fairing, with a height of $80 \mathrm{~cm}$. The fairing separated from both Sputnik and the spent R-7 second stage at the same time as the satellite was ejected. Tests of the satellite were conducted at OKB-1 under the leadership of Oleg G. Ivanovsky.

\section{First discoveries in space}

The first Russian and USA artificial satellites discovered Earth's radiation belts. J. van Allen (USA) discovered inner radiation belt by the satellites "Explorer 1" and "Explorer 3" (1958) and S. N. Vernov (USSR) discovered outer radiation belt with the satellites "Sputnik 2" and "Sputnik 3" (1957-1958) [3, 4].

Since properly interpreting the data from the Explorer and Sputnik satellites, scientists have wondered about the radiation belts' origins. It was obvious that cosmic rays themselves had too much momentum to become trapped. Soviet scientists Sergej Vernov and Alexander Lebedinsky of MSU proposed that when cosmic rays bombard Earth's atmosphere, they could produce nuclear reactions that create neutrons, which subsequently decay into electrons and protons that are then trapped by the planet's magnetic field [4]. The proposal was the first physical model to explain the nature of the radiation belts. Vernov and Lebedinsky 
announced the neutron-decay mechanism in July 1958, only a few months after the belts' discovery. Just two weeks later, US scientist Fred Singer independently published a description of a similar mechanism [4].

\section{Space surveillance and tracking in Bulgaria}

In 1956 the Soviet government addressed the Bulgarian government with a recommendation to start space research in Bulgaria in view of the future Russian program. In 1957, Dr. Eng. Georgi Nestorov (then Professor and Corresponding Member of the Bulgarian Academy of Sciences - BAS) [5-8] was commissioned to create in 1957 a special department to the Research Institute for Communications Radio-measuring Control and Ionospheric Center - RIKIC. In this department he attracted the future academicians - then young engineers, Kiril Serafimov and Dimitar Mishev, who grew up as scientists with world renown.

The Ionospheric Center began studying the propagation of radio waves in the ionosphere, using mainly the A+ method. Immediately after the launch of first artificial satellite on the Earth in orbit on October 4, 1957, RIKIC began to receive the signals from the on-board transmitter "Mayak" and analyze the Doppler Effect. With some interruptions, the study of the integral electron content in the ionosphere by BAS scientists continues to this day [9-11].

Nestorov measurements of the Doppler Effect: the satellite travels in a well-known path and broadcast their signals on two known radio frequencies 20.005 and $40.002 \mathrm{MHz}$. The received frequencies will differ slightly from the broadcasting frequencies due to the satellite movement relative to the receiver. By monitoring this frequency shift over a short period of time, the receiver can determine its location to one side or the other side of the satellite, and several such measurements combined with the exact knowledge of the satellite orbit can determine a certain position, for example, the height of the satellite.

Nestorov found that during the second and especially in the third week, "Sputnik 1" began to noticeably decrease its height due to its drag and friction with the substance in the upper atmosphere. Nestorov's proposed method of determining altitudes of satellites can be widely used in space research.

Subsequently, after 1958, optical, laser and radar observations of artificial satellites on Earth began to take place in Bulgaria. During the period 1958-1959 three observation stations were set up - in Sofia, Stara Zagora and Varna [12].

The visual, photographic and laser observations in Bulgaria continue until 2002, when they are gradually ceased to be performed due to a lack of funding and the moving of the world observation centers of the satellites to a higher technological level [12]. 


\section{World Space Week (WSW)}

On December 6, 1999, The United Nations General Assembly declared World Space Week as an annual event celebration to be commemorated between 4-10 October. The choice of dates was based on recognition of two important dates in space history: the launch of the first man-made Earth satellite "Sputnik 1" on October 4, 1957 and the signing of the Outer Space Treaty on October 10, 1967. World Space Week is the largest annual space event in the world. In 2017, World Space Week was celebrated with over 3700 events in 80 countries. Events included school activities, exhibitions, government events, and special activities at planetaria around the world.

Each year, a theme for World Space Week is established by the World Space Week Association. Under the theme "Exploring New Worlds in Space", many events of World Space Week 2017 focused on plans for human exploration of space and recent discoveries of Earth-like planets in nearby solar systems.

In 2018, the theme for World Space Week will be "Space Unites the World". This in part recognizes the historic UNISPACE+50 gathering to be held in Vienna this year. UNISPACE I held in Vienna from 14 to 27 August 1968. This was the first major space conference of the United Nations on the occasion of the $10^{\text {th }}$ anniversary of space age.

\section{References}

1. SPUTNIK-1. October 4, 1957: Dawn of the Space Age. https://www.space.com/17888first-satellite-sputnik-1-explained-infographic.html (accessed 20 December 2017)

2. Wade, M., Encyclopedia Astronautica, 2017. URL: www.astronautix.com

3. Stern, D.P., M. Peredo, The Exploration of the Earth's Magnetosphere, 12. The radiation belt - history, 2004. URL: http://www.phy6.org/Education/whradbel.html

4. Baker, D., M. Panasyuk, Discovering Earth’s radiation belts, Physics Today, 2017, 70 12, 46-56. DOI: 10.1063/PT.3.3791

5. Несторов, Г., М. Топалов, Предавателна, антенна и УКВ техника, Държавно издателство „Наука и изкуство“, София, 1955.

6. Несторов, Г., Разпространение на УК Вълни. Държавно издателство „Медицина и физкултура“, София, 1958.

7. Несторов, Г., Физика на ниската йоносфера. Издателство на Българската академия на науките, София, 1969.

8. Велинов, П., Г. Несторов, Л. Дорман, Воздействие космических лучей на ионосферу и распространение радиоволн, Издательство Болгарской Академии Наук, София, 1974.

9. Andonov, B., Vertical Total Electron Content and receiver bias calculations for Balkan Peninsula GNSS stations, C. R. Acad. Bulg. Sci., 2017, 70, 12, 1719-28.

10. Velinov, P.I.Y., S. Delistoyanov, D. Mishev, G. Nestorov, and Chr. Spassov, Ionospheric TEC measurements by informational radioline of satellite "MeteorPriroda", In: Remote Sensing of Earth by Satellite "Meteor-Priroda", St. Peterbourg, Gidrometeoizdat, 1985, 145-151. 
11. Mukhtarov, P., B. Andonov, and D. Pancheva, Empirical model of TEC response to geomagnetic and solar forcing over Balkan Peninsula. Journal of Atmospheric and Solar-Terrestrial Physics, 2018, 167, 80-95.

12. Ognyanov, O., Y. Shopov, P. Getsov, P. Malgova, A. Stoev, S. Kusin, and A. Pertcov, History, present and perspektives of space surveillance and tracking, In: Proceedings of SES'2017, 2017, 95-100.

\section{РАЗВИТИЕ НА СЬВРЕМЕННИТЕ КОСМИЧЕСКИ НАУКИ СЛЕД ПЪРВИЯ ИЗКУСТВЕН СПЪТНИК НА ЗЕМЯТА. бО ГОДИШНИНА НА КОСМИЧЕСКАТА ЕРА}

\section{П. Велинов}

\section{Резюме}

Представено е развитието на различните космически науки след изстрелването на първите изкуствени спьтници на Земята. Дадени са редица данни и параметри на първия изкуствен спътник „Спутник 1”. Показани са и първите открития на космическата ера - радиационните пояси на Земята, открити от ван Ален и Вернов. Представена е и историятата на радио наблюденията на „Спътник 1” в 22-дневния период на работата на спьтниковия предавател, 04-26 октомври 1957 г.

Първите радиоизмервания в България са направени от д-р Г. Несторов (впоследствие професор и член-кореспондент на БАН) от създаденото в началото на 1957 г. специално звено към Научно-изследователския институт по съобщенията - Радио-измервателен контролен и йоносферен центьр (РИКИЦ). Д-р Г. Несторов прави измервания на ефекта на Доплер и определя височината на спътника. Той установява, че през втората и особено през третата седмица „Спьтник 1“ започва да намалява чувствително височината си поради триенето си с веществото във високата атмосфера.

Впоследствие, след 1958 г. в България започват да се провеждат оптически, лазерни и радарни наблюдения на изкуствени спътници на Земята (ИС3). През периода 1958-1959 г. се създават три наблюдателни станции - в градовете София, Стара Загора и Варна. Тези наблюдения продължават до 2002 г., когато постепенно те престават да бъдат извършвани поради липса на финансиране и преминаване на световните наблюдателни центрове на повисоко технологично ниво. 